\title{
IMPLEMENTATION OF AN ELECTRONIC CIRCUIT FOR SSSA CONTROL APPROACH OF A PLATE TYPE ELEMENT AND EXPERIMENTAL MATCH WITH A FEED-FORWARD APPROACH
}

\begin{abstract}
Successful implementation of an active vibration control system is strictly correlated to the exact knowledge of the dynamic behavior of the system, of the excitation level and spectra and of the sensor and actuator's specification. Only the correct management of these aspects may guarantee the correct choice of the control strategy and the relative performance. Within this paper, some preliminary activities aimed at the creation of a structurally simple, cheap and easily replaceable active control systems for metal panels are discussed. The final future aim is to control and to reduce noise, produced by vibrations of metal panels of the body of a car. The paper is focused on two points. The first one is the realization of an electronic circuit for Synchronized Shunted Switch Architecture (SSSA) with the right dimensioning of the components to control the proposed test article, represented by a rectangular aluminum plate. The second one is a preliminary experimental study on the test article, in controlled laboratory conditions, to compare performances of two possible control approach: SSSA and a feed-forward control approach. This comparison would contribute to the future choice of the most suitable control architecture for the specific attenuation of structure-born noise related to an automotive floor structure under deterministic (engine and road-tyre interaction) and stochastic (road-tyre interaction and aerodynamic) forcing actions.
\end{abstract}

\section{Introduction}

The evolution of automobiles, as well as many other means of transport, is a process that concerns not only with the fields of performances and aesthetic qualities, but also with comfort and environmental aspects. Looking at the automobile sector, as an example, the necessity to develop lighter cars and the use of downsized reshaped thermal engines to reduce $\mathrm{CO}_{2}$ emissions implies the unsuitableness of

\footnotetext{
${ }^{1}$ Department of Industrial Engineering - Aerospace section, University of Naples "Federico II", Naples,Italy.Email: first.author@institute1.edu,second.author@institute1.edu,
} 
the already-used soundproofing systems. This is not a negligible problem, because high overall noise level, as well the presence in noise spectra of specific components (as those related to various rotating elements) could be perceived by buyers as a low quality indicator, in addition to represent a notable annoyance factor. All these considerations give evidence of the importance to develop new and more efficient noise insulating materials and technologies as those generally referred as "active control technologies". The opportunity to use these latter technologies could help to reduce the overall weight of the acoustic treatments that can produce an increment of consumption and a more considerable environmental impact [1,2]. Due to the peculiarities of the forcing signal that presents a superposition of a deterministic (engine and road-tyre interaction) and a stochastic (road-tyre interaction and aerodynamic) component, the stability of the overall architecture represents a crucial item. Among the available active control technology, this aspect needs to be strongly verified together with the computational effort required by each approach for a reliable implementation.

\section{Active control strategies}

A first definition of "Active Control" and "Passive Control" concepts may be introduced before the description of specific functions and implication of this control technique, Passive Control may be defined as the optimization of any mechanical system (in our particular case, a structure) to limit vibrations in its standard working conditions. So, passive control systems are essential parts of the structure. Active Control is a technological approach based on the "destructive interference" phenomenon: the sum of two signals, which are equal in amplitude but opposite in phase. Under these assumption we could say that while in the first case (passive) the control system has to dissipate energy, in the second (active) it supplies more energy to the structure for counteracting vibrations [3-5].

The necessity of integrate passive control system with active ones descends from the issue that the thickness of a soundproofing material has to be of the same order of magnitude of the wavelength of the signal to damp for being efficient: this means that, for low frequencies (typically up to $500 \mathrm{~Hz}$, in some conditions up to $1000 \mathrm{~Hz}$ ), the panel could be too thick, overloading the structure. On the other hand, active systems show application limitations due to the computational effort of the real time algorithms as well as the large amount of transducers to be implemented that generally is strongly related to the number of modes of vibration that needs to be controlled; these issues limits the bandwidth to the above mentioned $500 \mathrm{~Hz}$. In addition, passive control systems have the advantage of not needing energetic supply [6, 7].

Generally speaking, an active control system needs sensors, actuators and controllers that can be combined under different control strategies: a single couple actuator-sensor with a single-channel controller or more couples with a multi- 
channel controller. Looking at the first implementation of these concepts, three of the main categories in which we can classify the control structures are [8-12]:

- Feed-Forward: ideal type for controlling deterministic-type disturbances (like engine noise). The sensors measure the disturbance signal before it arrives on the structure and send it to a pack of filters (control system), which calculates it and then generates the control signals. These are sent to the error speakers to emit the wanted control noise.

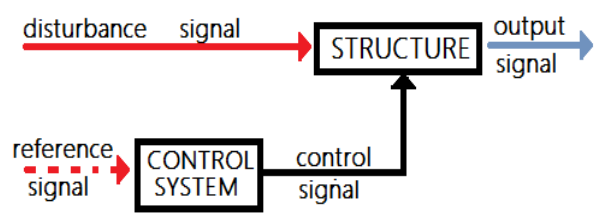

Fig. 1. Block diagram of the feed-forward control system

- Feed-Back: specific for random disturbances (aerodynamic noise, rolling tyre noise). The error signal, which has to be sent to the control system, is directly extracted from the noise emitted by the error speakers and then is sent in loop.

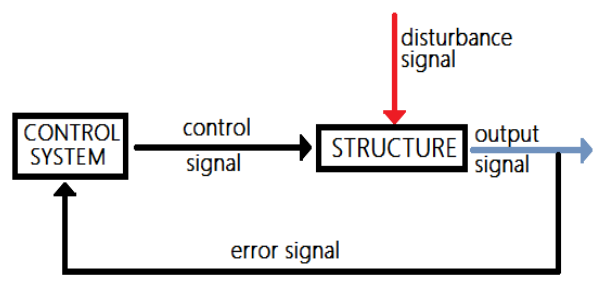

Fig. 2. Block diagram of a feed-back control system

- In some cases we can create a mixed-type control system, called FeedForward Closed Loop, specific for measurements of deterministic-type disturbances before they reach the structure. The control system receives one part of the signal directly from the disturbance and the other part from the error speakers.

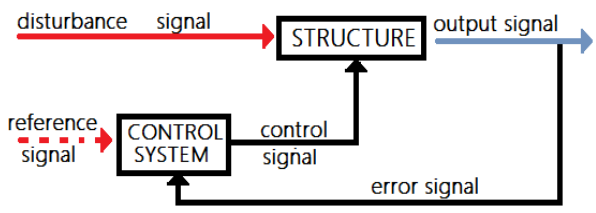

Fig. 3. Block diagram of an adaptive feed-forward control system with a feedback error evaluation 
The opportunity to use one scheme or the other strictly depends by the dynamic characteristic of the structure and the specific excitation field. A possible alternative control strategy, which is assuming an increasing relevance, is based on shunted piezoceramic technologies to damp structural vibrations and to reduce sound pressure level as well.

The reason of the interest and demands of designing a shunt circuit can be summarized as follows: the shunt circuit should often minimize structural vibration efficiently, with a good robustness against system parameter variations and with stability. This last is a typical advantage of a semi-active control strategy, which is the control family of the shunted piezoceramic systems. Furthermore, the shunt circuit should not require power for operation and the weight and cost of the implemented circuit should be kept low.

Besides the system doesn't require a complex control strategy, which must be implemented and managed through a programming language by an expensive programmable digital hardware. Instead the management of the control strategy is totally of analogic type and it is guaranteed by few and very economic electronic components.

This approach of control through shunted piezoceramics considers different possible architectures:

- Resistive Shunts: the connection of a piezoelectric transducer to a resistor dissipating structural energy by heat. This is a very cheap and easy solution to implement but damping performance is very poor [13].

- Capacitive Shunts: networks of capacitors which can be shunted on piezoelectric transducers. This technique changes the stiffness of the transducer and therefore the natural frequency and modal damping ratio of a piezoelectric actuator are altered. In this method, the shunt circuit is only used to change the stiffness of the piezoelectric transducer and thus changing natural frequency of the piezoelectric mechanical damper $[14,15]$.

- Resonant Shunts: they are a more efficient family like single mode R-L or resonant multi-mode shunts [13, 15-18].

These types of shunts generate an electrical resonance with the piezoelectric capacitance. If this electrical resonance is tuned to one of the structural modal frequencies, a considerable effective damping of the corresponding mode is achieved. Generally, all resonant shunts suffer from the drawback that their damping performance is very sensitive to variations in the system's parameters. In this case, the resonant shunts get mistuned and do not damp anymore.

Therefore, online tuned resonant shunts have been proposed in literature $[19,20]$. However, the suggested tuning algorithms have not shown satisfying results, as they are very slow, difficult to implement and do not converge well.

- Switching Shunts: these circuits implement switches to change the dynamics of the shunt in such a way that the vibration damping can be improved. Switching shunts seem to be promising for an implementation that does 
not require power, because the switches can be realized with MOSFETs that require meaningless power to be switched and the small amount of power, required to switch the MOSFETs, could be supplied by an additional piezoelectric patch. Switching R-L shunts have been proposed by [21, 22].

In the present work with the aim to obtain a good performance without having to tune the system, it is considered a switching passive circuit, which opens and closes at a precise timing. This system, which is the main object of the study, uses the electrical charge stored on the piezoelectric elements to counter the vibrations, with an effect similar to dry damping. As the switch timing is synchronized on the vibrations, no precise tuning is required; the system is self-adaptive and can be self-powered.

In the next pages it is described the experimental activity performed about the control of an aluminum plate, used as test article, adopting two different control strategies and comparing their results. The first one will be a Synchronized Shunted Switch Architecture (SSSA), belonging to the fourth class of the previous list and an active control which is a feed-forward in an open loop system.

\section{Test article}

The mock-up chosen as test article for this preliminary study is a simple aluminum plate, since metal panels in cars can be considered as plate-type components. The aluminum plate has a thickness of $1.5 \mathrm{~mm}$, and total dimensions of $505 \times 405 \mathrm{~mm}$. The plate is clamped on the edges with two iron frames, which are applied to both faces and fixed with screws, which pass through the plate too (Fig. 4). The free surface, which isn't covered by two iron frames, has dimensions of $444 \times 344 \mathrm{~mm}$.

On the plate are installed three square-shaped piezoelectric components provided by Stelco GmbH. Two piezo (PPK-23 material) are glued on the front face and marked with letters "A" and "B" (Fig. 4). The first one will be used to excite the plate (exciting piezo) and the second one as an actuator for the control strategies tested in the experimental activity (controller piezo). About the problem of the good location of the piezo-actuator and piezo-sensor on a rectangular plate, which is a relevant point for an active vibration damping system, especially for a few first mode shapes of the plate [23], the position of piezo B was chosen, considering the results of numerical/experimental tests, performed in [24]. Piezo B working as actuator piezo in the SSSA control approach, was collocated in the region where the maximum deformation for the first modes of the structure is expected. Another patch (PPK-11 material) is glued on the back face of the plate in the same position of the Piezo "B" and it is marked with letter "C". The latter one will be used as sensor piezo to convert local deformation, where it is applied in a voltage signal. The choice of piezo " $\mathrm{C}$ " as sensor derives from considerations that this element has the highest gain (conversion ratio) stated in a previous work [24]. Piezo C is located in the same position of " $\mathrm{B}$ " but on the opposite face of the plate because 


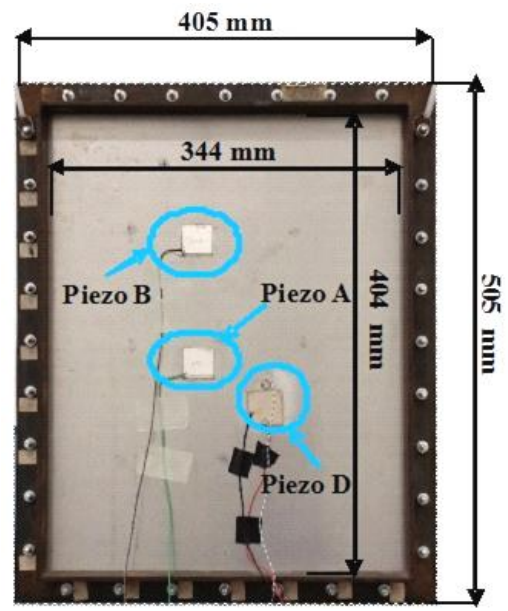

Fig. 4. Front view of aluminum plate

in the SSSA approach it is generally required that the piezo element, working as sensor, is the nearest position to the actuator piezo.

Also, another piezo is installed on the front side of the plate, marked with letter "D", it was used as actuator to excite mechanically the plate in the phase of its dynamic characterization of the plate (Fig. 4) [24].

The experimental set-up consisted of a signal generator, which produced the perturbation signal, sent to a multi-channel amplifier and then to the Piezo A (exciting piezo), an oscilloscope including spectrum analyzer and a "Polytec@ PSV-400 scanning vibrometer" used for a more complete dynamic characterization of the plate under different conditions. Clearly the set-up includes an electronic circuit implementing the "synchronized switched shunt architecture" (SSSA) to regulate the controller (semi-active control), described in the next section.

\section{Electronic circuit for SSSA}

In this section the synchronized switched shunt architecture" (SSSA) and its implementation through an electronic circuit, is described. Fig. 5 shows a schematic representation of the complete SSSA control system. It consists of a switching control unit connected to the shunt branch RL and a piezoelectric transducer device. The piezoelectric transducer is connected to the shunt branch through the switch control unit, which drives the CMOS switch device.

The switch control unit is described in detail as being made of a:

- Derivative \& LPF (Low Pass Filter) unit: the input to the Derivative \& LPF Unit is the PZT transducer voltage, converting the structural strain through the $\mathrm{g} 31$ (direct) piezoelectric constant. In fact, since the tachometer is sensitive to a zero crossing signal while the switch activation must be synchronized to the maximum strain, the input must be opportunely derived. 


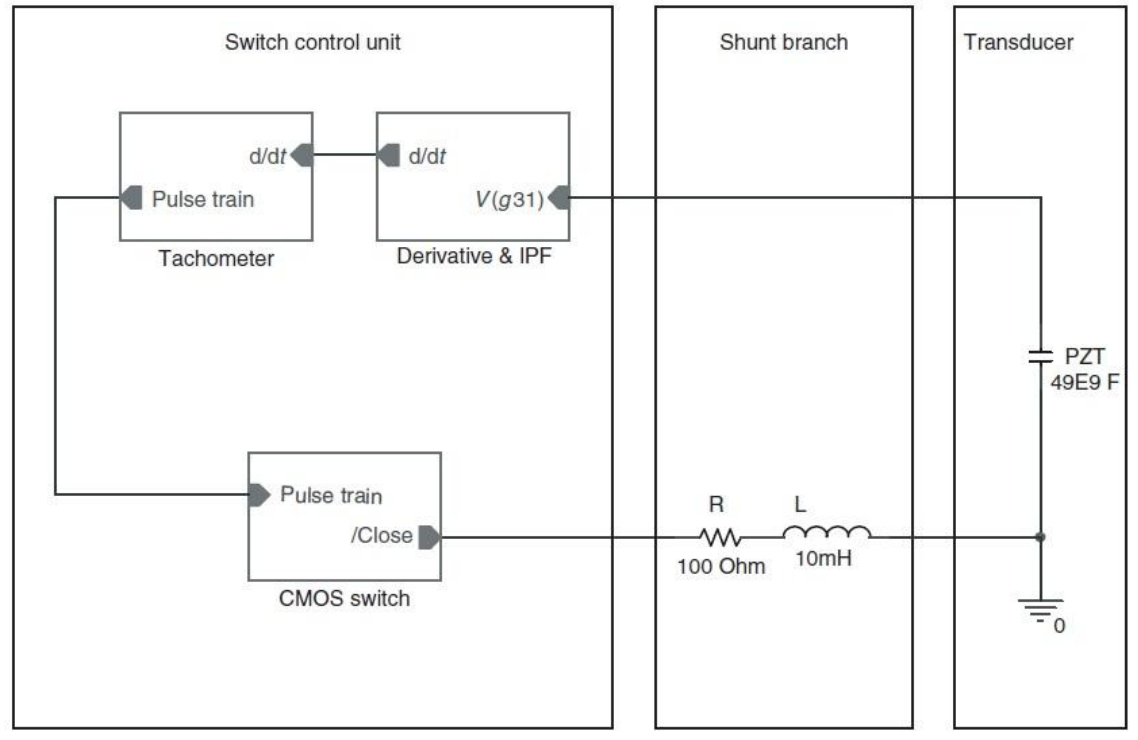

Fig. 5. Scheme of the SSSA control system

- Tachometer: the tachometer input is the derived excitation signal. The tachometer output is a pulse-train signal. The circuitry is able to produce the signal synchronized with the maxima deformations and with the width of $1 / 10$ of the input signal period. The component used belongs to the LM2907 series. In keeping with the system building block concept, this device provides an output voltage which is proportional to input frequency and provide zero output at zero frequency.

- CMOS switch: the switch component is a solid state device, typically a CMOS transistor, in order to face the high frequencies and the high number of commutations. CMOS construction ensures ultra-low power dissipation, making the parts ideally suited for portable and battery-powered instruments. The CMOS switch driving input signal is a pulse train. The output is an off/on state.

The working principle consists of synchronizing the 'on state' of switch component with the maximum absolute values for the strains of the piezo sensor (blue curve of Fig. 6). When this event occurs, the switch device is on for about 1/10 of the highest excitation signal period to be controlled and the voltage from the switched shunt piezoelectric element (red curve in Fig. 6) inverts its sign.

During the on state, the piezo charge flows through the inductor which sends it back, reversed, to piezo leads, producing an impulsive strain, opposite to the vibration that generated it. Because $\mathrm{C}$ is fixed by the piezo element, a suitable value should be set for $\mathrm{L}$, to optimize the device performance.

An upper limit for the inductance should be also considered, to ensure that the stored charge (inside the piezo element) remains approximately constant while the 


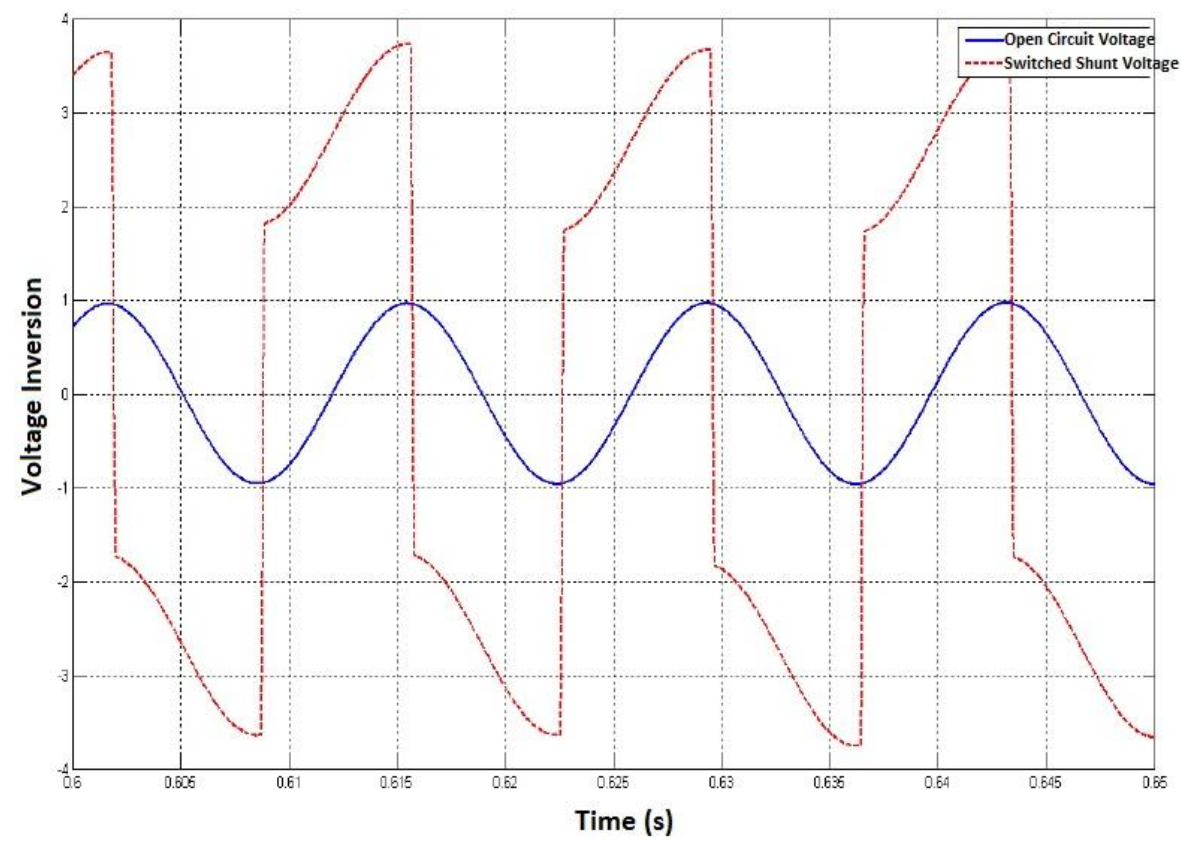

Fig. 6. Synchronizing of switch activation with absolute maximum values of strains of the piezo sensor

switch is on. The lower limit for the inductance is quite arbitrary, apart the necessity to prevent the excitation of structural resonance modes by the switch action. The inductance is calculated by:

$$
\begin{gathered}
L=\frac{1}{4 \pi^{2} C\left(f_{E l e}\right)^{2}} \\
f_{\text {Ele }}=10 f_{\text {Mec }}
\end{gathered}
$$

with: $f_{M e c}$ - maximum mechanical frequency which must be controlled by the system (in our case $f_{M e c}=500 \mathrm{~Hz}$ ), $C$ - capacity of the system.

Because in our case $f_{M e c}=500 \mathrm{~Hz}$ and $C=15 \mathrm{hF}$ (which is the capacity of the B Piezo Controller), results a value of inductance $L=67 \mathrm{mH}$.

The electronic circuit was built in the laboratory of Department of Industrial Engineering.

\section{Experimental activity and results}

The complete dynamic characterization of the plate, both under the numerical and experimental point of view, as widely been described within a previous work [24]. In the present paper, the experimental control activities will be introduced: the 
first is addressed to the implementation of a Feed-forward active control scheme and the second to SSSA system. Relative results will be compared and discussed.

Along both the experiences, the vibration primary field has been generated by the excitation of piezo "A" boned on the plate and powered through a signal generator and an associated power supply. In more detail, two frequencies have been decided to be excited at $69 \mathrm{~Hz}$ and $122 \mathrm{~Hz}$ specifically tuned at the first and second flexural resonance frequency of the plate. In the feed-forward experience, the same signal is send to the controller and then to the control piezo "B", as the classic feed-forward architecture requires. The 'error sensor' $\mathrm{C}$ is used as a feedback to the control law, while the Polytec Laser Doppler is used to show the overall dynamic response of the plate. The sensor piezo " $\mathrm{C}$ " is able, in fact, to produce a voltage signal related with the local deformations of the point, where it is applied, instead the laser, through a scanning operation on a grid of points can reveal velocities of those points. In the following pictures first a comparison of the signal by sensor piezo " $\mathrm{C}$ " and after a comparison of color map for velocity and displacement of grid points, are reported both in the situations of control activated and deactivated.

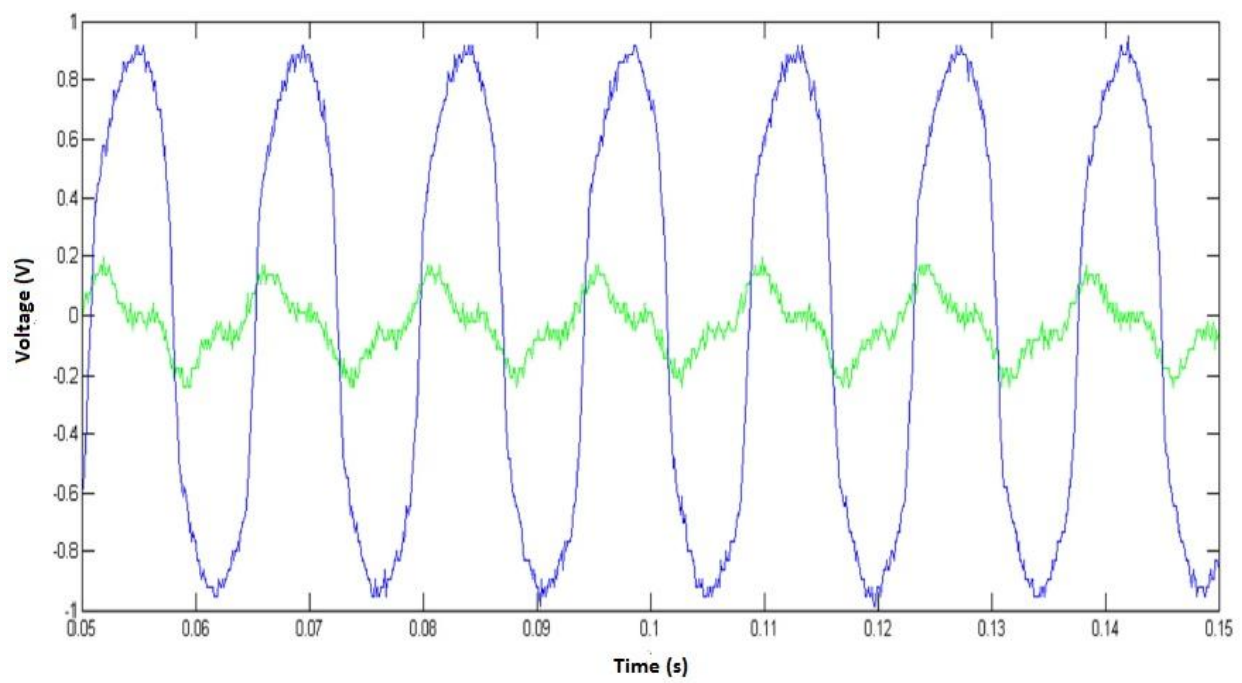

Fig. 7. Signal by Sensor Piezo "C". Without control (blue), with control (green)

It can be observed a strong reduction of the signal from piezo sensor " $\mathrm{C}$ " when the control is active and also an overall reduction of displacement level. As expected, the activation of the control system does not affect the dynamic shape, being the control working at resonance conditions. As Fig. 8 shows, the maximum value for the Color Map of displacement (red region) decreases from $250 \mu \mathrm{m}$ to $120 \mu \mathrm{m}$. A reduction is gained also in the case of excitation at $122 \mathrm{~Hz}$ where the maximum value for the Color Map of displacement decreases from $10 \mu \mathrm{m}$ to $7 \mu \mathrm{m}$. 


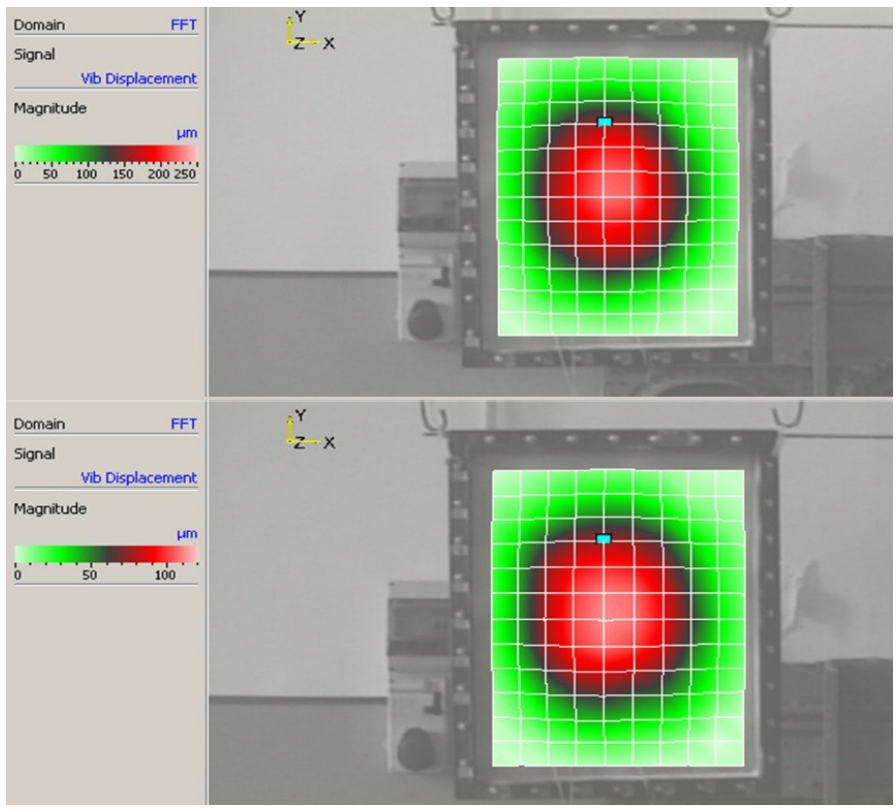

Fig. 8. Color Map of Displacement $(69 \mathrm{~Hz})$ without control (up) and with control (down)

Next Table 1 summarizes all the results of this first experimental; data comparison are reported for both the investigated frequencies also in terms of vibration velocity because this physical quantity is directly related to the radiated acoustic power.

Table 1.

Summary results with active feed-forward

\begin{tabular}{|c|c|c|c|c|}
\hline $\begin{array}{c}\text { Freq. } \\
(\mathrm{Hz})\end{array}$ & Control & $\begin{array}{c}\text { Velocity } \\
(\mathrm{mm} / \mathrm{s})\end{array}$ & $\begin{array}{c}\text { Displacement } \\
\text { in the location } \\
\text { of Piezo C } \\
(\mu \mathrm{m})\end{array}$ & $\begin{array}{c}\text { Sensor } \\
(\mathrm{mV})\end{array}$ \\
\hline 69 & OFF & 67.6 & 156.0 & 966.7 \\
\hline 69 & ON & 33.7 & 77.2 & 176.2 \\
\hline 69 & $\%$ difference & $-50 \%$ & $-50 \%$ & $-82 \%$ \\
\hline 122 & OFF & 8.2 & 10.7 & 793.2 \\
\hline 122 & ON & 5.3 & 6.9 & 74.6 \\
\hline 122 & $\%$ difference & $-35 \%$ & $-35 \%$ & $-91 \%$ \\
\hline
\end{tabular}

The second session of experimental activities has then been dedicated to the plate's behavior under the "synchronized switched shunt" controller effect. Also in this configuration, piezo "A" has been used as primary field generator now the second piezo "B", is connected the RL branch to the SSSA. The scan grid and the scan parameters for the laser are the same of the previous active control case. 
In the SSSA case the maximum value for the Color Map of displacement (red region) decreases from $400 \mu \mathrm{m}$ to $160 \mu \mathrm{m}$. A reduction is gained also in the case of excitation at $122 \mathrm{~Hz}$ where the maximum value for the Color Map of displacement decreases from $8 \mu \mathrm{m}$ to $6 \mu \mathrm{m}$.

The results at a frequency value of 69 and $122 \mathrm{~Hz}$ are summarized in Table 2. It can be observed that the maximum of reduction is gained in the case of $69 \mathrm{~Hz}$ where the system shows a better performance; at the frequency of $122 \mathrm{~Hz}$, the local deformation, measured by piezo sensor, presents a good reduction while an increase of the velocity and the displacement values (about $+12 \%$ ) is measured when control is 'on'. In any case, the level of the physical measured quantities are extremely low.

Table 2.

Summary results with SSSA

\begin{tabular}{|c|c|c|c|c|}
\hline $\begin{array}{c}\text { Freq. } \\
(\mathrm{Hz})\end{array}$ & Control & $\begin{array}{c}\text { Velocity } \\
(\mathrm{mm} / \mathrm{s})\end{array}$ & $\begin{array}{c}\text { Displacement } \\
\text { in the location } \\
\text { of Piezo C } \\
(\mu \mathrm{m})\end{array}$ & $\begin{array}{c}\text { Sensor } \\
(\mathrm{mV})\end{array}$ \\
\hline 69 & OFF & 125.61 & 289.72 & 264.76 \\
\hline 69 & ON & 48.734 & 112.41 & 135.52 \\
\hline 69 & $\%$ difference & $-61 \%$ & $-61 \%$ & $-49 \%$ \\
\hline 122 & OFF & 6.079 & 7.93 & 24.031 \\
\hline 122 & ON & 6.83 & 8.9 & 13.8 \\
\hline 122 & $\%$ difference & $12 \%$ & $12 \%$ & $-43 \%$ \\
\hline
\end{tabular}

\section{Conclusions}

To improve the soundproofing of car's cabin, especially when referring to structure-borne components, it is required the development of a structurally simple, cheap and easily replaceable active control systems for metal panels of the car body. Before the experimentation on the real test articles, a first preliminary study on an simpler test article and in more controlled laboratory conditions has been performed, comparing two possible approach: Synchronized Shunted Switch Architecture (SSSA) and feed-forward control. After the experimental phase it is evident that the SSSA carries a good reduction of vibration signal but the overall performance is poorer than the Active Feed-Forward Control. This result was already expected on the basis of theoretical consideration, but is has also to be taken into account the intrinsic stability of SSSA architecture especially when facing multi harmonic signals and when no reference signal is available. It is also evident the light and robust electronic architecture of the system that would not require super visioning processors. On the other hand, are well known, the drawback of adaptive feed-forward architecture in these situations, as well as the computational 
effort required to the controller. In any case, this activity, represent only the beginning of an articulated program that will drive to the refinement of the control architecture to be faced with more complex situation and signal contents.

\author{
Manuscript received by Editorial Board, March 08, 2016;
} final version, November 18, 2016.

\title{
References
}

[1] M. Viscardi and L. Lecce. Active skin for noise control. In Proceedings of the Tenth International Congress on Sound and Vibration, pages 3743-3747, Stockholm, Sweden, 2003.

[2] J. Qiu, H. Ji, and K. Zhu. Semi-active vibration control using piezoelectric actuators in smart structures. Frontiers of Mechanical Engineering in China, 4(3):242-251, 2009.

[3] M. Viscardi and L. Lecce. An integrated system for active vibro-acoustic control and damage detection on a typical aeronautical structure. In Conference on Control Applications Proceedings, 1, pages 477-482, Glasgow, UK, 2002.

[4] M. Viscardi and L. Lecce. Experiences of active vibration control-on typical aeronautical structures. In International Symposium on Active Control of Sound and Vibration, Budapest, Hungary, 21-23 August 1997.

[5] P.A. Nelson and S.J. Elliott. Active Control of Sound. Academic Press, London, 1992.

[6] P.A. Nelson. The behaviour of multichannel LMS algorithms in active control applications. In Proceedings of IEEE Workshop on Applications of Signal Processing to Audio and Acoustic, New York, USA, 1989.

[7] E.F. Crawley and J. De Luis. Use of piezoelectric actuators as elements of intelligent structures. AIAA Journal, 25(10):1373-1385, 1987.

[8] L. Lecce, M. Viscardi, and G. Zumpano. Multifunctional system for active noise control and damage detection on a typical aeronautical structure. In SPIE's 8th Annual International Symposium on Smart Structures and Materials, pages 201-212, San Diego, USA, 2001. doi: $10.1117 / 12.436531$.

[9] L. Lecce, M. Viscardi, and S. Cantoni. Active vibration control by piezoceramic actuators on a jet aircraft partial frame structure. In 3rd International Conference on Intelligent Materials, pages 706-711, 1996.

[10] L. Lecce, M. Viscardi, D. Siano, and D. Concilio. Active noise control in a fuselage section by piezoceramic actuators. In Proceedings of Active 95 - The 1995 International Symposium on Active Control of Sound and Vibration, pages 595-606, Newport Beach, CA, USA, July 1995.

[11] C.H. Hansen and S.D. Snyder. Active Control of Noise and Vibration. E\& FN Spon, London, UK, 1997.

[12] C.R. Fuller, S.J. Elliott, and P.A. Nelson. Active Control of Vibration. Academic Press, London, UK, 1996.

[13] N.W. Hagood and A. von Flotow. Damping of structural vibrations with piezoelectric materials and passive electrical networks. Journal of Sound and Vibration, 146(2):243-268, 1991.

[14] G.A. Lesieutre, C.L. Davis, and J.J. Dosch. Piezoceramic vibration control device and tuning control thereof, 27 February 2001. US Patent 6,193,032.

[15] C.L. Davis, G.A. Lesieutre, and J.J. Dosch. Tunable electrically shunted piezoceramic vibration absorber. In Proceeding SPIE Smart Structures and Materials 1997, pages 51-59, San Diego, CA, USA, March 1997.

[16] R.L. Forward. Electronic damping of vibrations in optical structures. Applied Optics, 18(5):690697, 1979. 
[17] M.S. Tsai and K.W. Wang. On the structural damping characteristics of active piezoelectric actuators with passive shunt. Journal of Sound and Vibration, 221(1):1-22, 1999.

[18] S.O.R. Moheimani. A survey of recent innovations in vibration damping and control using shunted piezoelectric transducers. IEEE Transactions on Control Systems Technology, 11(4):482-494, 2003.

[19] D. Niederberger, A. Fleming, S.O.R. Moheimani, and M. Morari. Adaptive multi-mode resonant piezoelectric shunt damping. Smart Materials and Structures, 13(5):1025, 2004.

[20] J. Kim and J.-Y. Choi. Passive piezoelectric damping tuned by using measured electrical impedance. In SPIE's 8th Annual International Symposium on Smart Structures and Materials, pages 420-431, Newport Beach, CA, USA, March 2001.

[21] A.J. Fleming and S.O.R. Moheimani. Adaptive piezoelectric shunt damping. Smart Materials and Structures, 12(1):36, 2003.

[22] C. Richard, D. Guyomar, D. Audigier, and H. Bassaler. Enhanced semi-passive damping using continuous switching of a piezoelectric device on an inductor. In SPIE's 7th Annual International Symposium on Smart Structures and Materials, pages 288-299, Newport Beach, CA, USA, March 2000.

[23] A. Koszewnik and Z. Gosiewski. Quasi-optimal locations of piezo-elements on a rectangular plate. The European Physical Journal Plus, 131(7):232, 2016.

[24] M. Viscardi and R. Di Leo. Structural dynamic characterization of a plate type element oriented at active control implementation. In Recent Researches in Mechanical and Transportation Systems, Proc. of the $6^{\text {th }}$ International Conference on Automotive and Transportation Systems, pages 206-212, Salerno, Italy, June 27-29 2015.

Implementacja układu elektronicznego do sterowania drganiami elementu płytowego metodą synchronicznie kluczowanego bocznika oraz eksperymentalne porównanie z układem wykorzystującym sterowanie ze sprzężeniem wyprzedzającym

Streszczenie

Udana implementacja układu aktywnej kontroli drgań jest ściśle uwarunkowana dokładną znajomością dynamicznych właściwości obiektu, poziomu i zawartości widmowej wymuszeń, a także parametrów czujników i elementów wykonawczych. Jedynie właściwe uwzględnienie wszystkich tych aspektów może zagwarantować poprawny wybór strategii sterowania i wynikające z niej działanie systemu. $\mathrm{W}$ pracy przedstawiono i przedyskutowano wyniki badań wstępnych ukierunkowanych na stworzenie prostego strukturalnie, taniego i łatwo wymienialnego aktywnego systemu sterowania, przeznaczonego dla paneli metalowych. Ostatecznym celem ma być kontrola i ograniczenie hałasu wytwarzanego przez drgające płyty metalowe w nadwoziu samochodu. Artykuł koncentruje się na dwu zagadnieniach. Pierwszym z nich jest realizacja układu elektronicznego działającego $\mathrm{w}$ architekturze synchronicznie kluczowanego bocznika (SSSA), z elementami dobranymi odpowiednio do sterowania testowanym obiektem, którym jest prostokątna płyta aluminiowa. Drugim celem jest wstępne studium doświadczalne nad zachowaniem się obiektu badanego, w kontrolowanych warunkach laboratoryjnych, służące porównaniu dwu możliwych koncepcji sterowania: z wykorzystaniem architektury synchronicznie kluczowanego bocznika (SSSA) oraz sterowania ze sprzężeniem wyprzedzającym. W przyszłości wyniki porównania ułatwią dokonanie wyboru architektury sterowania najwłaściwszej dla tłumienia hałasu strukturalnego wytwarzanego przez podłogę nadwozia samochodu pod wpływem wymuszeń deterministycznych (pochodzących od silnika i interakcji między oponami i nawierzchnią) oraz stochastycznych (aerodynamicznych i interakcji opona-nawierzchnia). 